\title{
The Knowledge Level of Turkish Rheumatoid Arthritis Patients about Their Diseases
}

\section{Türk Romatoid Artrit Hastalarının Hastalıkları Hakkındaki Farkındalık Düzeyi}

\begin{abstract}
Aim: This study aims to assess the level of disease specific knowledge of the patients with Rheumatoid Arthritis

Materials and Methods: A total of 225 RA patients were included in this study. Patients' demographic and clinic data and information resources were recorded. In order to evaluate the awareness levels of patients, the "Patient Knowledge Questionnaire in Rheumatoid Arthritis (PKQ-RA)" was used.

Results: The mean age and disease duration of patients were found to be $52.8 \pm 10.8$ and $6.7 \pm 6.5$ years, respectively. Most of the patients (86.7\%) reported that they had gained the information about RA from their physicians. Internal consistency of the Turkish version of PKQ-RA was high with Cronbach's alpha of 0.71 and test-retest intra-class correlation coefficient was 0.94 . The total PKQ-RA scores were 15.1 \pm 12.6 (ranging: 0-27). Patients' knowledge levels differentiated according to their age, education, socioeconomic status, and family history of disease.

Discussion and Conclusion: This is the first study to investigate Turkish RA patients' awareness levels of the disease. Having insufficient information about the disease has always been a general problem in RA patients. In this study, it was determined that the knowledge levels of our patients were not significantly high. Thus, to be able to increase the patients' awareness, some individualized precautions should be taken by physicians.
\end{abstract}

Keywords: Rheumatoid arthritis; awareness; education; treatment

Öz

Amaç: Bu çalışmanın amacı Romatoid Artrit hastalarının hastalıkla ilişkili farkındalık düzeyini belirlemektir.

Materyal Metod: Çalışmaya toplam 225 RA hastası alındı. Hastaların demografık ve klinik verileri ile bilgi kaynakları kaydedildi. Farkındalık düzeyini değerlendirmede "Romatoid Artrit Hasta Farkındalık Anketi " kullanıldı.

Sonuçlar. Hastaların ortalama yaşı $52.8 \pm 10.8$ ve hastalık süresi $6.7 \pm 6.5$ yıldı. Hastaların çok büyük kısmı (\%86.7) bilgi kaynağının doktoru olduğunu ifade etti. Romatoid Artrit Hasta Farkındalık Anketi'nin Türkçe versiyonunun iç tutarlıık değeri Cronbach alfa'sı 0.71 ve test-retest korelasyon katsayısı 0.94

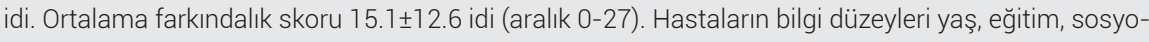
ekonomik durum ve ailede hastalık öyküsünün olup olmamasından etkilenmekteydi.

Tartışma: Bu çalışma Türk RA hastalarının farkındalık düzeyinin değerlendirildiği ilk çalışmadır. RA hastalarının hastalıkları hakkında yetersiz bilgiye sahip olmaları global bir sorundur. Bu çalışmada RA hastalarımızın farkındalık düzeyinin çok yüksek olmadığını saptadık. Bu nedenle de farkındalığı artıracak bireye özgü bir takım önlemler almamız gerektiği sonucuna vardık.

Anahtar Sözcükler. Romatoid artrit; farkındalık; eğitim; tedavi
Gulnur Tasci Bozbas, Gulcan Gurer

Department of Physical Medicine and Rehabilitation, Adnan Menderes University Medical Faculty, Aydin, Turkey

Geliş Tarihi /Received : 07.03.2017 Kabul Tarihi /Accepted: 09.05.2017

DOI: 10.21673/anadoluklin.325831

Sorumlu Yazar/Corresponding Author Assist Prof Gulnur Tasci Bozbas E-mail: gulnurtb@yahoo.com 


\section{INTRODUCTION}

Rheumatoid Arthritis (RA) is a common chronic disease that affects joints. It is a serious health problem that affects about 8-16 thousand individuals annually (1). If remission is not achieved in a RA patient, joint destruction, functional disability and organ damages may occur. Therefore, early diagnose and treatment is very important. The treatment of RA must be multidimensional. Along with medical treatment, to regulate the rest and exercise and to adjust to limitations of the disease is highly important. As in all chronic diseases, the patient education in RA is very important so that the treatment can be performed effectively $(2,3)$.

Patient education is very important for the patient to comply with the treatment, to change behaviors and thus to prevent disability (3-5). The precondition of education is to decide patient knowledge; because the equilibrium between what patients is in need of and what physician wants to teach should be well set when the contents of the training programs are being decided (2). If RA patients' needs are not taken into consideration in the contents of education, the education will remain only as a routine program applied by health workers and it will not function properly (6-8). In EULAR's recommendation related to inflammatory arthritis it stated that the content of patient education should be individualized and arranged according to the needs of patient (9). Various studies have shown that individual patient education improves health outcomes (9-13).

The knowledge level of Turkish RA patients has not been evaluated previously. Therefore, in this study, we aimed to assess the level of disease specific knowledge of the the Turkish RA patients', the factors affecting it and their information resources.

\section{METHOD}

The University Ethics Committee approved the study protocol, and the study was conducted in accordance with the Declaration of Helsinki. Patients were diagnosed with rheumatoid arthritis (RA) according to the American College of Rheumatology's (ACR) 2010 criteria, which are included in this descriptive cross- sectional study. All participants were assured that all information provided would be kept confidential.

A patient knowledge questionnaire on rheumatoid arthritis (PKQ-RA), developed by Hill et al. (14), was used, consisting of 16 questions with one, two, or three correct answers; all questions included an alternative answer of "I don't know." A total score of 30 correct responses out of a maximum of 80 possible responses. The results were categorized into subgroups a) general knowledge, including etiology, symptoms, and tests (maximum score: 9); b) drugs (maximum score: 7); c) exercise regimens (maximum score: 7); and d) joint protection (maximum score: 7).

Turkish translation of the PKQ-RA has not been completed, and for this reason, the adaptation of the questionnaire was made according to internationally accepted guidelines for the process of cross-cultural adaptation (15). This process consists of five stages. First, the original language was translated into Turkish by two bilingual translators. Second, inconsistencies in the translations were discussed among the translators and one health professional to resolve any translation issues. Third, two additional translators translated the Turkish version of the questionnaire back to the original language to validate that the translated version contained the same content as the original version. Fourth, the healthcare professional and all translators reviewed the final translations and developed a pre-final version of the questionnaire for field testing. Finally, a pretest was conducted among 15 RA patients of various ages and educational levels. Each patient completed the questionnaire and was interviewed to determine opinions of each questionnaire item and the chosen response.

The patients' comments were analyzed by two healthcare professionals, which necessitated some modifications in accordance with the Turkish RA population. It was found that none of the patients provided a correct response to the question: "Can you choose two blood tests to assess how active your arthritis is?" This question was revised to address C-reactive proteins. In addition, no patients were able to respond correctly to the D-penicillamine response for the question: “Can you choose two long-term drugs?” In 1991 
Table 1. Rheumatoid Arthritis Patients' Demographic and Clinic Characteristics and Their Effects on the Awareness Levels

\begin{tabular}{|c|c|c|c|c|}
\hline & $\mathbf{n}$ & $\%$ & mean \pm SD & $\mathbf{p}$ \\
\hline \multicolumn{4}{|l|}{ Gender } & \multirow{3}{*}{ * } \\
\hline Woman & 173 & 76.9 & $14.3 \pm 5.5$ & \\
\hline Man & 52 & 23.1 & $14.8 \pm 4.8$ & \\
\hline \multicolumn{5}{|l|}{ Education } \\
\hline İlliterate & 10 & 4.4 & $9.7 \pm 3.3$ & \\
\hline Elementary (8 years) & 141 & 62.7 & $13.6 \pm 5.1$ & \multirow[t]{2}{*}{$* *$} \\
\hline High School & 50 & 22.2 & $16.9 \pm 4.9$ & \\
\hline University & 24 & 10.7 & $15.8 \pm 5.6$ & \\
\hline \multicolumn{5}{|l|}{ Socioeconomic Status } \\
\hline$<500 \mathrm{TL}$ & 24 & 10.7 & $11.6 \pm 5.4$ & \\
\hline $500-1000 \mathrm{TL}$ & 56 & 24.9 & $13.1 \pm 5.1$ & ** \\
\hline $1000-2000 \mathrm{TL}$ & 80 & 35.6 & $15.1 \pm 5$ & \\
\hline$>2000 \mathrm{TL}$ & 65 & 28.9 & $15.7 \pm 5.4$ & \\
\hline Information & & & & \multirow{3}{*}{ ** } \\
\hline Sufficient & 160 & 71.1 & $15.0 \pm 5.3$ & \\
\hline Insufficient & 65 & 28.9 & $12.8 \pm 5.0$ & \\
\hline \multicolumn{4}{|l|}{ Treatment } & \multirow{3}{*}{ * } \\
\hline Non-biological & 193 & 85.7 & $14.2 \pm 5.2$ & \\
\hline Biological & 32 & 14.3 & $15.3 \pm 6.3$ & \\
\hline \multicolumn{4}{|c|}{ Hospitalization due to RA } & \multirow{3}{*}{ * } \\
\hline Present & 90 & 40 & $14.5 \pm 5.1$ & \\
\hline Absent & 135 & 60 & $14.3 \pm 5.5$ & \\
\hline \multicolumn{5}{|l|}{ RA history in family } \\
\hline Present & 44 & 19.6 & $15.8 \pm 4.6$ & ** \\
\hline Absent & 181 & 80.4 & $14.0 \pm 5.4$ & \\
\hline
\end{tabular}

when the PKQ-RA was developed, use of methotrexate in RA therapy was not as widespread as it is today (16); therefore, D-penicillamine was changed to methotrexate on the translated questionnaire. The final version was tested for reliability to ensure internal consistency, which is an estimate of the degree to which its constituent items are interrelated, using Cronbach's alpha coefficient. Finally, the test-retest reliability of the Turkish version of the PKQ-RA was evaluated using the intra-class correlation coefficient [ICC $(1,1)](17)$, and 39 patients were assessed twice in two-week intervals.

The study included 225 volunteering patients with RA who were assessed at the rheumatology outpatient clinic in Adnan Menderes University between March 2015 and January 2017. Patients with mental or per- ceptual deficits were excluded from this research., Demographic data such as age, gender, education status, and socio-economic level, and clinical data, such as the duration of disease, the medications used, the number of annual controls, hospitalization due to RA, and familial history, were recorded. The patients were asked if they felt they had sufficient knowledge of the disease and the sources of existing information.

Statistical analysis were performed using SPSS Statistics for Windows, version 18.0. Cronbach's alpha internal consistency reliability was computed to assess internal consistency for the overall score of the translated PKQ-RA. The test-retest reliability was assessed by intra-class correlation coefficient [ICC $(1,1)$ ] Clinical-demographical characteristics of the patients were analyzed using descriptive statistics (means and standard deviations). With respect to data analysis, frequencies and proportions were used to describe the characteristics of this sample as well as the PKQ-RA for each item. For group comparison, we used t-test in continuous variables with normal distribution and Mann-Whitney $U$ test in those with abnormal distribution. $\mathrm{p}<0.05$ was regarded as statistically significant.

\section{RESULTS}

Internal consistency of the Turkish version of PKQ-RA was high with Cronbach's alpha of 0.71. The test-retest ICC was 0.94 . The demographic characteristics of the subgroup of patients used in test-retest reliability analysis were similar to the main group (mean age $52.9 \pm 10.6,72 \%$ female, disease duration $6.8 \pm 6.4$ ).

The mean age of patients was $52.8 \pm 10.8$ years (ranging: $23-75$ years) and $76.9 \%$ were women. The duration of RA ranged from 0.5 to 40 years (mean $6.7 \pm 6.5$ years). The number of annual control visits was $5.8 \pm 2.8$ (ranging: 2-14). Demographic and clinic features were summarized in Table 1 . The total PKQ scores were $15.1 \pm 12.6$ (ranging: 0-27). When patients' information sources were evaluated, $86.7 \%$ of patients reported they obtained information from their physicians, $29.8 \%$ from internet, $22.7 \%$ from other patients, $19.1 \%$ from radio-television, $10.2 \%$ from books and $5.3 \%$ from friends. On the other hand, $71.1 \%$ of the 
Table 2: The rates of correct answers to the questions

\begin{tabular}{|c|c|c|c|}
\hline \multicolumn{2}{|r|}{ Questions } & $\%$ & $\%$ \\
\hline \multicolumn{3}{|c|}{ General knowledge } & \\
\hline \multirow{2}{*}{ 1) Rheumatoid Arthritis } & the cause is not known & 41.3 & \multirow{2}{*}{8.9} \\
\hline & may be triggered by a bacteria or virus & 17.8 & \\
\hline \multirow{2}{*}{ 2) Rheumatoid Arthritis } & occasionally affects the lungs, eyes or other tissues & 46.7 & \multirow{2}{*}{39.1} \\
\hline & is along-term disease & 72.4 & \\
\hline \multirow{3}{*}{$\begin{array}{l}\text { Which can be caused by Rheumatoid } \\
\text { Arthritis? }\end{array}$} & anaemia & 57.3 & \multirow{3}{*}{23.1} \\
\hline & nodules & 44.4 & \\
\hline & fatigue & 67.1 & \\
\hline \multirow{2}{*}{$\begin{array}{l}\text { 4) Blood tests are used to assess the disease } \\
\text { activity }\end{array}$} & Erythrocyte sedimentation rate(ESR) & 42.5 & \multirow{2}{*}{35.6} \\
\hline & C-reactive protein. & 38.1 & \\
\hline \multicolumn{3}{|c|}{ Drugs and how to take them } & \\
\hline \multirow{2}{*}{ 5) Non-steroidal anti-inflammatory drugs } & they reduce pain, swelling and stiffness & 61.3 & \multirow{2}{*}{22.8} \\
\hline & they should be taken with food & 39.1 & \\
\hline $\begin{array}{l}\text { 6) Most common side-effect of non-steroidal } \\
\text { anti-inflammatory tablets }\end{array}$ & indigestion & 39.1 & \\
\hline \multirow{2}{*}{$\begin{array}{l}\text { Long-term drugs which can put the disease } \\
\text { into remission }\end{array}$} & Methotrexate & 56.0 & \multirow{2}{*}{30.7} \\
\hline & Sulphasalazine & 38.2 & \\
\hline \multirow{2}{*}{ 8) Pain killing tablets } & should only be taken when pain is severe & 64.9 & \multirow{2}{*}{33.5} \\
\hline & should be taken when pain starts to build up & 48.9 & \\
\hline \multicolumn{3}{|l|}{ Exercise regimens } & \\
\hline \multirow{2}{*}{ 9) Exercise and RA } & move your joint to the point of pain and then a bit further & 34.2 & \multirow{2}{*}{19.6} \\
\hline & exercise can reduce th echance of a joint deforming & 36.9 & \\
\hline \multirow{2}{*}{$\begin{array}{l}\text { Most suitable ways for someone with RA to } \\
\text { take regular exercise }\end{array}$} & muscle tightening exercises & 44 & \multirow{2}{*}{36.0} \\
\hline & walking & 71.6 & \\
\hline $\begin{array}{l}\text { 11) Which you should carry out when all your } \\
\text { joints are painful and stiff }\end{array}$ & carry out your usual range of movement exercises & 44.9 & \\
\hline \multirow{2}{*}{$\begin{array}{l}\text { Which would be most suitable if your wrists } \\
\text { are becoming more than usually painful, } \\
\text { swollen and stiff }\end{array}$} & $\begin{array}{l}\text { avoid movement by keeping them in one position as much } \\
\text { as possible }\end{array}$ & 52 & \multirow{2}{*}{26.7} \\
\hline & $\begin{array}{l}\text { Put the joints through a full range of movement several } \\
\text { times a day }\end{array}$ & 57.8 & \\
\hline \multicolumn{3}{|l|}{ Joint protection } & \\
\hline \multirow{2}{*}{$\begin{array}{l}\text { 13) The most practical way to protect your } \\
\text { joints from strain is to }\end{array}$} & $\begin{array}{l}\text { Use the larger joints rather than the smaller ones where } \\
\text { possible }\end{array}$ & 33.3 & 21.6 \\
\hline & Slide objects rather than lift them & 56.9 & \\
\hline $\begin{array}{l}\text { 14) The most suitable activity when you have a } \\
\text { busy day planned but realize you're feeling } \\
\text { tired }\end{array}$ & do essentials and leave the rest & 51.6 & \\
\hline 15) The suitable methods of conserving your & sit down whils tironing & 38.7 & 212 \\
\hline energy & Plan activities to balance work and rest periods & 62.3 & \\
\hline 16) The methods of joint protection & $\begin{array}{l}\text { Use the palm of your hands not your fingers when } \\
\text { opening a jar }\end{array}$ & 62.7 & 21.3 \\
\hline & Having power assisted steering on your car & 28.4 & \\
\hline
\end{tabular}

patients thought that they had sufficient information.

Table II shows rates of correct answers to the questions. The mean general RA knowledge score was $4.3 \pm 2.4$. Only three patients answered all the questions in this group correctly, whereas 8 patients could answer none of them (ranging; 0-9). Most of the patients knew that RA was a long-standing disease and could lead to fatigue. $42.2 \%$ of patients thought wet and cold 
weather would cause the disease and 52\% had no idea about the blood tests used in assessment of disease activity. Drug-knowledge related to treatment of RA was $3.4 \pm 1.6$ (ranging; 0-6). 13 patients had no idea about the medication used in RA treatment; no one answered the questions in this group correctly. $42.9 \%$ of patients had no idea about the non-steroidal anti-inflammatory drugs. The mean knowledge score of RA patients about exercise was $3.4 \pm 1.7$ (ranging, $0-7$ ). In RA the knowledge about the exercise was $3.4 \pm 1.7$ (ranging, 0-7). 11 patients ( $4.9 \%$ ) had no idea about this topic and only 6 patients $(2.7 \%)$ replied all these questions correctly. $36 \%$ of patients had no idea about the effects of exercise and $24 \%$ thought that they did not need to do any exercise when they lived active. 30.2\% thought they should avoid from all exercises when the disease is active. The mean knowledge score about joint protection was $3.3 \pm 1.5$ (ranging; $0-7$ ). While 11 patients (4.9\%) had no idea about this topic only 2 patients (0.9\%) answered all questions correctly. In order to protect joints, $43.9 \%$ of patients assumed that they should maintain normal activity as long as arthritis is absent, whereas $36.9 \%$ thought they should avoid from all activities. 52.9\% believed that the furniture should be carried with both hands to save energy.

It was also found that the level of patient knowledge decreased with age $(\mathrm{p}<0.05)$. The knowledge levels in patients who thought that they had sufficient information before were significantly higher compared to those who did not have $(\mathrm{p}<0.05)$. The level of knowledge was positively influenced by education level, socioeconomic status and present of RA disease in family $(\mathrm{p}<0.05)$. No significant difference was found between the duration of RA disease, number of annual visits, hospitalization status and awareness ( $\mathrm{p}>0.05)$. There was no difference between awareness of those who used conventional "Disease Modifying Drugs" (DMARDs) (n:193) and biologic DMARDs (n:23) (p>0.05) (Table 1).

\section{DISCUSSION}

For chronic diseases such as RA, sufficient information is very important for increasing patient com- pliance with treatment and willingness to take preventive precautions (2). Therefore, patient education is an integral part of RA management (16). Several studies have demonstrated that increasing knowledge through patient education decreases RA disabilities (18-20), and effective management of chronic conditions must be based on shared decision making between patients and healthcare providers (6). Patient education is an easy-to-implement and cost-effective method for improving patients' knowledge of the disease, with the only prerequisite being to determine what patients' already know about RA (6). Thus, the PKQ-RA developed by Hill et al. is frequently used to assess RA patient knowledge (14).

The Turkish version of this questionnaire was given to 50 RA patients and had good reliability with a Cronbach's alpha coefficient of 0.71 and test-retest reliability with an ICC of 0.94. Several studies have been conducted to assess patient knowledge of RA $(1,2,16,21)$, but this is the first study that evaluated the level of knowledge among Turkish RA patients. It was found that Turkish patients' have inadequate knowledge, similar to results obtained by Hill and Heliwelin among English RA patients, and that they have less knowledge than Brazilian RA patients $(14,16,18)$. Having insufficient information about the disease is a general problem among RA patients $(14,16)$. For example, regular exercise has positive effects on the disease (22); however, few Turkish RA patients exercise regularly, which has been associated with insufficient information about the effects of exercise (23). The current study also found that RA patients do not have sufficient information about exercise and its relationship to RA.

In previous studies, patient knowledge increased as education level increased $(18,24)$. Generally, modest awareness was attributed to lower education and socio-economic levels $(14,20)$. In this study, it was found that young patients had higher awareness levels of RA, as in previous study $(2,18,24-26)$. Hennel and Neame found women to be more knowledgeable about the disease; however, no difference between genders was found for the current study population $(18,24)$. Pytel et al. found that, as in our study, knowledge levels of patients who had a family history of RA were higher 
compared to those who did not (1). Generally, awareness level is not influenced by the duration of disease, as in our study $(14,16,27,28)$. Barlow et al. found that RA patients with shorter disease durations, in particular, benefited from education (28). Most RA patients receive information about the disease from doctors, although most still have insufficient knowledge $(29,30)$. Neither hospitalization due to RA nor frequent visits to doctors affected knowledge levels, possibly due to failure to allocate enough time for training during routine visit of doctors or to develop special training programs. Loring stated that lower awareness levels may result from physicians not considering patient training as a part of therapy; thus, training activities should be modified to help patients take advantage of the information available to them (31).

Approximately one fifth of patients stated they received information about RA from other RA patients. Therefore, it must be kept in mind that each informed patient affects other patients. Correct information publicized through the internet and radio or television programming was also very important for increasing patient knowledge, and in addition to doctors, RA patients also received information from rheumatology nurses $(6,12,13,25,29,32)$. In Turkey, a specialized RA nursing group is not available; therefore, establishing rheumatology nursing may help increase awareness of RA among Turkish patients. If patients cannot receive sufficient information from healthcare personnel, they will collect data from other resources, which could be insufficient or incorrect and may complicate therapy by leading patients toward erroneous behaviors (1).

In this study, $28.9 \%$ of patients thought they did not have sufficient information about RA, and this group's awareness level was explicitly lower compared to those who thought they had enough information. During healthcare visits, patients should be asked whether they have sufficient information about RA, and training should be provided to those who answer negatively. Additionally, the information level of patients who did believe they had sufficient information was not high, and it was concluded that awareness among such patients should be questioned and train- ing should be provided on topics they are unfamiliar with. These types of evaluations are very important to show patients that they do not have sufficient information about the disease, which should increase interest in RA education. It was reported that patients who actively participated in training benefited more from these programs than those who did not $(2,28,33)$. One-on-one training can be provided during doctors' visits or group sessions, but to be effective, the level of information patients already possesses must be verified. In this study, RA patients' knowledge levels varied significantly (PKQ score range $0-27$ ), and to expect a heterogeneous patient group to take advantage of the same training program would be optimistic. This situation indicates that training should be patient-specific. If group training programs are to be arranged, developing content consistent with the knowledge that patients lack increases the effectiveness of the program.

Consequently, this study is important because it is the first study to investigate Turkish RA patients' awareness levels of the disease. At the end of the study, action will be taken to increase patient knowledge, and it is hoped that the study results will aid future researchers.

\section{Acknowledgement}

The authors acknowledge Ozge Ozceylan, Emre Ozceylan and Aysegul Yavuz for the translation and back translation of the PKQ-RA

\section{REFERENCES}

1. Pytel A, Wrzosek Z. Estimation of patient knowledge on rheumatoid arthritis in the range of their own diseasepreliminary study. Adv Clin Exp Med. 2012;21:343-51.

2. Polluste K, Kallikorm R, Lember M. Level of knowledge and sources of information about the rheumatoid arthritis in Estonian patients. Rheumatol Int 2014;34:675-81.

3. American College of Rheumatology Ad Hoc Committee on Clinical Guidelines. Guidelines for the management of rheumatoid arthritis. Arthritis Rheum 1996;39:713722.

4. Viller F, Guillemin F, Briancon S, Moum T, Suurmeijer T, van den Heuvel W. Compliance to drug treatment of patients with rheumatoid arthritis: a 3 year longitudinal study. J Rheumatol 1999;26:2114-22. 
5. Hill J, Bird H. Patient knowledge and misconceptions of osteoarthritis assessed by a validated self-completed knowledge questionnaire (PKQ-OA). Rheumatology 2007;46:796-800.

6. .Ndosi M, Johnson D, Young T, Hardware B, Hill J, Hale $\mathrm{C}$, et al. Effects of needs-based patient education on selfefficacy and health outcomes in people with rheumatoid arthritis: a multicentre, single blind, randomised controlled trial. Ann Rheum Dis. 2016;75:1126-32.

7. Dequeker J, Rasker JJ, Woolf AD. Educational issues in rheumatology. Bailliére's Clin Rheum 200;14: 715-29.

8. Kyngäs H). Patient education: Perspective of adolescents with a chronic disease. Journal of Clinical Nursing 2003;12:744-51.

9. Zangi HA, Ndosi M, Adams J, Andersen L, Bode C, Boström C, et al. EULAR recommendations for patient education for people with inflammatory arthritis.Ann Rheum Dis 2015;74:954-62.

10. Albano MG, Giraudet-Le Quintrec JS, Crozet C, d'lvemois JF. Characteristics and development of therapeutic patient education in rheumatoid arthritis: analysis of the 2003-2008 literature. Joint Bone Spine 2010;77:405-10.

11. Marks R. Self-efficacy and arthritis disability: an updated synthesis of the evidence base and its relevance to optimal patient care.Health Psychol Open 2014;23:1-18.

12. Gronning K, Skomsvoll JF, Rannestad T, Steinsbekk A. The effect of an educational programme consisting of group and individual arthritis education for patients with polyarthritis -a randomised controlled trial. Patient Educ Couns 2012;88:113-20.

13. Gronning K, Rannestad T, Skomsvoll JF, Rygg LO, Steinsbekk A. Long-term effects of a nurse-led group and individual patient education programme for patients with chronic inflammatory polyarthritis-a randomised controlled trial. J Clin Nurs 2014;23:1005-17.

14. Hill J, Bird HA, Hopkins R, Lawton C, Wright V. The development and use of Patient Knowledge Questionnaire in rheumatoid arthritis. Br J Rheumatol. 1991;30:45-9.

15. Beaton DE, Bombardier C, Guillemin F, Ferraz B. Guidelines for the process of cross-cultural adaptation of selfreport measures. Spine 2000;25:3186-91.

16. Jennings F, Toffolo S, de Assis MR, Natour J. Brazil Patient Knowledge Questionnaire (PKQ) and evaluation of disease-specific knowledge in patients with rheumatoid arthritis. Clin Exp Rheumatol. 2006;24(5):521-8.
17. Shrout PE, Fleiss JL. Intraclass correlation: uses in assess-ing rater reliability. Psycho Bull 1979;86:420-8

18. Hennell SL, Brownsell C, Dawson JK. Development, validation and use of a patient knowledge questionnaire (PKQ) for patients with early rheumatoid arthritis. Rheumatology (Oxford). 2004;43:467-71.

19. Maggs FM, Jubb RW, Kemm JR. Single-blind randomised controlled trial of an educational booklet for patients with chronic arthritis. Br J Rheumatol 1996;35:775-7.

20. Helliwell PS, O’hara M, Holdsworth J, Hesselden A,King T, Evans P. A 12-month randomized controlled trial of patient education on radiographic changes and quality of life in early rheumatoid arthritis. Rheumatology (Oxford) 1999;38:303-8.

21. Sierakowska M, Klepacka M, Sierakowski SJ, Pawlak-Buś $\mathrm{K}$, Leszczyński P, Majdan M, et al. Assessment of education requirements for patients with rheumatoid arthritis, based on the Polish version of the Educational Needs Assessment Tool (Pol-ENAT), in the light of some health problems - A cross-sectional study. Ann Agric Environ Med 2016;23:361-7.

22. Knittle KP, De Gucht V, Hurkmans EJ, Vlieland TP, Peeters AJ, Ronday HK, et al. Effect of self-efficacy and physical activity goal achievement on arthritis pain and quality of life in patients with rheumatoid arthritis. Arthritis Care Res (Hoboken) 2011;63:1613-9.

23. Bal A, Ataman Ş, Bodur H, Rezvani A, Paker N, Tastekin $\mathrm{N}$, et al. Characteristics of Patients With Rheumatoid Arthritis in Turkey: Results From the Turkish League Against Rheumatism Rheumatoid Arthritis Registry. Arch Rheumatol 2015;30:16-22.

24. Neame R, Hammond A, Deighton C. Need for information and for involvement in decision making among patients with rheumatoid arthritis: a questionnaire survey. Arthritis Rheum 2005;53:249-55.

25. Meesters J, de Boer I, van den Berg M, Fiocco M, Vliet Vlieland T. Unmet information needs about the delivery of rheu-matology health care services: a survey among patients with rheumatoid arthritis. Patient Educ Couns 2011;85:299-03.

26. Makelainen P, Vehvilainen-Julkunen K, Pietila AM Rheumatoid arthritis patients' knowledge of the disease and its treatments: a descriptive study. Musculoskelet Care 2009;7:31-44.

27. Lineker SC, Badley EM, Hughes EA, Bell MJ. Development of an instrument to measure knowledge in individuals with rheumatoid arthritis: The ACREU Rheuma- 
toid Arthritis Knowledge Questionnaire. J Rheumatol 1997;24:647-53.

28. Barlow JH, Cullen LA, Rowe IF. Comparison of knowledge and psychological well-being between patients with a short dis-ease duration ( $\leq 1$ year) and patients with more established rheumatoid arthritis ( $\geq 10$ years duration). Patient Education and Counseling 1999; 38:195203.

29. Schouffoer A, Zirkzee EJM, Henquet SM, Caljouw MAA, Steup-Beekman GM, van Laar JM et al. Needs and preferences regarding health care delivery as perceived by patients with systemic sclerosis. Clin Rheumatol 2011;30:815-24.
30. Cutilli CC. Seeking health information: what sources do your patients use? Orthop Nurs 2010;29:214-9.

31. Lorig K. Patient education: treatment or nice extra. Br J Rheumatol 1995;34:703-6.

32. Makelainen P, Vehvilainen-Julkunen K, Pietila AM. Rheumatoid arthritis patients' education - contents and methods. J Clin Nurs 2007;16:258-67.

33. Kirwan JR, Hewlett S, Cockshott Z, Barrett J. Clinical and psychological outcomes of patient education in rheumatoid arthritis. Musculoskeletal Care. 2005;3:1-16 